Chapter in: Kuhlman, S. \& Bouckaert, G. (eds.) (2016). Local Public Sector Reforms in Times of Crisis: National Trajectories and International Comparisons. London: Palgrave.

\title{
Municipal waste management in
}

\section{Norway and the Netherlands - from in-} house provision to inter-municipal

\section{cooperation}

Harald Torsteinsen and Marieke van Genugten

\section{Introduction}

In this chapter, we describe and compare the institutional development of municipal waste management in Norway and the Netherlands. Our focus is on the period from the 1970s to the present. We explore how local governments have reorganised internally and externally in this period of shifting and varying financial pressures. The guiding assumption of the book is that the organisation of local public services has gone through three developmental stages, from originally being organised in-house, through the New Public Management-epoch of disaggregation, autonomisation and contractualisation (Pollitt et al., 2004), maybe even privatisation, to the contemporary period of post-NPM and re-municipalisation (Wollmann \& Marcou, 2010). The research question in this chapter relates to whether these developmental stages can be observed in the field of municipal waste management in Norway and the Netherlands. We compare these two 
countries because they are relatively similar in many respects but quite different in terms of crisis experience. While the term crisis may be true in the case of the Netherlands in the 1980s ('the Dutch disease') and the post-2008 period, Norway has so far managed to sail clear of the worst effects of the international regressions, due to its strong oil-lubricated economy (Löffler, 2003: 479; Statistics Norway, 2008). This difference in terms of crisis experience leads us to expect that reform pressures may have been stronger in the Netherlands and thus have resulted in a different reform trajectory or different organisational solutions than in Norway. Furthermore, the local government systems of Norway and the Netherlands show significant similarities but at the same time exhibit important differences. Lidström (1996) for instance labels Norway as North European and the Netherlands as Napoleonic, while John (2001) describes both countries as belonging to the northern group, although he also recognises the legacy of Napoleonic influences on Dutch local government. A basic characteristic of the Nordic welfare states is the dominating role of local government, primarily municipalities in public service provision. The Napoleonic system is characterised by a strong centralised state, detailed control of local government by state prefects and mayors appointed by national government. However, decentralisation reforms have gradually reduced the differences between countries belonging to this group and the Nordic countries (Lidström, 1996), and this is certainly true at the local government level in the Netherlands. These similarities would lead us to expect a similar reform trajectory in both countries.

To address the research question and these expectations, we use a typology developed by Van Thiel (2012). This typology enables us to analyse whether the emergence of organisational forms in the three different stages has occurred in the same or in different ways in the field of waste management in both countries.

We find that the trajectory of reform in Norway and the Netherlands does not match the assumption of the three developmental stages as expected. Moreover, there are 
significant differences between the two countries in the way waste management is organised in these stages. In the Netherlands, the most significant NPM-related changes have taken place in the 1970s and 1980s, while in Norway these have taken place from the 1990s onwards. In relation to the last stage, we do not find any convincing signs of re-municipalisation in any of the two countries in the field of waste management. We do however observe a strong tendency towards 'inter-municipalisation' in a variety of forms, in spite of differences in terms of crisis experience.

In the following sections, we first present a typology of agencies before addressing the policy field of waste management. Thereafter, we analyse the three stages of local institutional reform in this field. The chapter concludes with a comparative discussion where we try to explain why the two countries which have marked differences in crisis experience end up with a rather similar institutional response in the policy field of waste management.

\section{Conceptualisation}

Describing and analysing public service provision across national borders can often be a challenging task in terms of identifying comparable organisational forms and finding common labels. This is not only a problem of language but also of institutional and legal regulations and traditions. In this section, we present a theoretical framework related to agentification theory and based on a typology developed by Van Thiel (2012). The intention is to make comparison between the two countries easier, irrespective of differences in language and institutional legacy.

Agentification ${ }^{1}$ may be defined as a process whereby local government (as principal) starts to disaggregate its service provision into more or less autonomous operative units

\footnotetext{
${ }^{1}$ We prefer this term instead of agencification in order to underline a link to agency theory and to make the approach more general.
} 
or agencies (agents) and regulates the relationship between itself and these units by contracts or quasi-contracts (Pollitt et al., 2004). Although this perspective was originally applied for analysing processes at the national level, we find it useful for processes at the local level as well. In Table 1 we use this perspective to identify the institutional forms at the local government level in Norway and the Netherlands.

Table 1. Types of agencies at the local level in Norway and the Netherlands

\begin{tabular}{|c|c|c|}
\hline Type & Definition & Forms at the local level \\
\hline 0 & Unit or directory of the local government & $\begin{array}{l}\text { Traditional in-house provision: } \\
\text { decentralisation rather than } \\
\text { agentification }\end{array}$ \\
\hline 1 & $\begin{array}{l}\text { Semi-autonomous organisation, unit or } \\
\text { body without legal independence but } \\
\text { with considerable managerial autonomy }\end{array}$ & $\begin{array}{l}\text { In-house provision by 'agentified' units } \\
\text { or municipal companies (in N: } \\
\text { resultatenheter and kommunalt foretak } \\
\text { (KF); in NL: gemeentebedrijven) and } \\
\text { forms of inter-municipal cooperation } \\
\text { that are not legally independent }{ }^{2}\end{array}$ \\
\hline 2 & $\begin{array}{l}\text { Legally independent organisation with } \\
\text { managerial autonomy (in principle public } \\
\text { law based) }\end{array}$ & $\begin{array}{l}\text { Inter-municipal companies (in NL: } \\
\text { Gemeenschappelijke Regeling (GR), in } \\
\mathrm{N} \text { : interkommunalt selskap (IKS)) }\end{array}$ \\
\hline 3 & $\begin{array}{l}\text { Organisation established by or on behalf } \\
\text { of the local government such as a } \\
\text { foundation, corporation, company or } \\
\text { enterprise (private law based) }\end{array}$ & $\begin{array}{l}\text { Limited companies (in N: aksjeselskap } \\
\text { (AS); in NL: overheidsvennootschappen) }\end{array}$ \\
\hline 4 & $\begin{array}{l}\text { Tendering and contracting out to public } \\
\text { (for example other municipalities) or } \\
\text { private organisations }\end{array}$ & \\
\hline
\end{tabular}

Source: based on Van Thiel (2012: 20).

Type 0 agencies are actually not agencies and not at arm's length from local government. This type comprises traditional in-house provision. Type 1 agencies are at arm's length from local government but do not have legal personality, while type 2 and 3 agencies do have legal personality. Type 2 agencies are public law based, while type 3 agencies are

\footnotetext{
${ }^{2}$ We discuss the different types in the two countries in the next sections.
} 
private law based. With regard to type 4 agencies, the local government that contracts out to a public or private organisation does not have an ownership relation with that organisation as is the case in type 2 and 3 agencies.

\section{The policy field of waste management}

In most Western European countries waste management is a municipal responsibility, although in some cases (Ireland, Italy, Spain and the UK) the service is split between, for instance, the county/province and the municipality (John, 2001: 36). In Norway, this responsibility is primarily linked to household waste where municipalities also have a monopoly. The Pollution and Waste Disposal (PWD) Act of 1981 instructs municipalities to 'make arrangements for the collection of household waste' (§ 30), and no one may collect this type of waste without the consent of the municipality. The law has been amended several times, the last time in 2013. The Norwegian Environment Agency $(\mathrm{NEA})^{3}$ has the supreme authority to oversee and regulate how the municipalities practice their obligations according to this law. It may also order municipalities to collect special waste and oblige owners/manufacturers of this type of waste and industrial waste to deliver it to a municipal waste treatment centre. Over time, public regulations have gradually become stronger and more detailed, for example, requiring separate collection and treatment of different types of refuse. Fees for household waste are determined by the municipal councils and should not exceed the actual total cost of providing the service.

In the Netherlands, traditionally household waste collection has been the concern of municipalities and was practiced initially only on a small scale. With the increase in the amount of waste, the Dutch central government thought it necessary to develop a more integrated approach to waste disposal. With the Waste Act of 1979 (integrated into the Environmental Management Act in 1994) public bodies at various government levels

\footnotetext{
${ }^{3}$ Miljødirektoratet.
} 
were given legally specified tasks and responsibilities regarding the formulation, operationalisation and implementation of waste policy (De Jong \& Wolsink, 1997). The provinces were responsible for formulating plans on the disposal of household waste, while municipalities were responsible for the implementation of these plans (Vereniging van Nederlandse Gemeenten, 1979). Dutch waste collection policy focuses on prevention and separation of waste and specific recycling circuits. Prevention is one of the main priorities of waste policy. Since 1994, municipalities have had the obligation to supply an infrastructure for separate collection of organic waste. In addition, they have to provide facilities for the separate collection of glass, paper, textiles, electronic products and hazardous materials. Furthermore, local authorities are free to decide how citizens have to pay for waste collection, on the basis of a volume-, frequency-, bag- or weight-based pricing system.

\section{Institutional set-up of municipal waste management}

A major challenge in describing and analysing the organisational development of waste management is the lack of research in the field (Smith, 2014). At this stage, therefore, we have to resort to a combination of general description of municipal service provision organisation, case studies and public statistics.

\section{Public-centred delivery}

Norway (pre-1990s)

During the 20-25 year period from the mid-1960s to the mid-/late 1980s, Norwegian municipalities went through several reforms intent on enabling them to harness the task of implementing ambitious national welfare policies: the amalgamation reform in 1964 and the reorganisation reform in the 1980s, aligning four political subcommittees and administrative structure. Public services, especially within the dominating policy areas of education and health and social services, requiring formal professional training and authorisation, were placed in the hands of public employees (type 0). As for technical 
services, including waste management, the situation seems to have varied more, for instance, depending on size and density of population and settlement patterns. Traditionally, there has been a more pragmatic openness to the use of private subcontractors in this field (type 0 and 4). Therefore, when the PWD Act of 1981 placed the responsibility for providing household waste collection and treatment in the hands of the municipalities, they were free to organise it as they saw fit.

\section{The Netherlands (pre-1980s)}

In the Netherlands, waste management has long since been a task for the municipalities. In the nineteenth century and the first half of the twentieth century, local governments established municipal services to collect and dispose of household waste (type 0). Although municipalities bear the responsibility for the periodical collection of household waste from any property on the municipalities' territories, already under the Waste Act of 1979 municipalities are explicitly allowed to decide whether to provide this service inhouse, to contract it out to a private firm (type 4) or to organise household waste collection in cooperation with other municipalities (type 2). Local governments were even encouraged to cooperate in household waste management (VNG, 1979). Furthermore, in 1950 a special law, the Joint Provisions Act, was enacted to stimulate and regulate cooperation between municipalities (Hulst, 2005: 101).

\section{NPM reforms}

\section{Norway (1990s onwards)}

While the waves of neo-liberalism and NPM spread in the 1980s, first in the Englishspeaking countries and later in Europe and other parts of the world, Norwegian public opinion and the public sector seemed rather hesitant and even reluctant to embark on this voyage. Olsen (1996) used the metaphor 'tortoise' to describe Norway's position. It was during the 1990s that the NPM ideas first started to influence public discourse and reforms in any significant way (Klausen \& Ståhlberg, 1998). 
In 1992 the new Local Government Act was passed, opening up opportunities for municipalities to organise their administrations generally as they liked. The act marked a milestone in the development of Norwegian local government, gradually leading to less standardisation and more variation in organisational forms. This new freedom seems to have opened up a window of opportunity for the introduction of NPM-inspired principles and practices. A general feature of the reforms now emerging was to separate politics and administration and to design arm's length structures. Two reforms, with special relevance for our topic, illustrate this feature: the 'agency' model and the municipal companies.

The first reform, the agency model, is an example of internal agentification - Van Thiel (2004) uses the term internal autonomisation - whereby service-providing units, for instance, waste services, are structurally more separated from the strategic apex of the municipal administration and given a higher degree of autonomy to make decisions concerning internal operational matters (economy, personnel, organisation) than before. They remain however legally integrated parts of the municipality. Also, contract-like agreements were set up to formulate the performance obligations of the agency managers towards the municipal CEO (Torsteinsen, 2012). In other words, they were transformed into type 1 'agents' in relation to the 'principal', the CEO (rådmann).

The second reform, the creation and use of municipal companies (type 2 and 3 ) in public service-provision, also gained momentum during the 1990s (Ringkjøb et al., 2008; Bjørnsen et al., 2015). Besides many pragmatic grounds, there was a strong belief that 'companification' or 'corporatisation' would result in greater transparency, thereby making accountability and control easier to obtain. Further, many grounds for introducing company forms had a pragmatic character. For example, the traditional organisational set-up in local government was perceived as less and less adapted to the growing scope and complexity of municipal service provision. This explanation, in addition to the fact that Norwegian municipalities are rather small, may have made 
municipal companies an attractive solution, especially within policy fields of low political controversy like, for instance, waste management. Service provision through municipal companies makes it easier to facilitate and formalise inter-municipal cooperation, thereby avoiding highly controversial amalgamation processes.

The private law limited company (AS) is the most prevalent form and accounts for more than 80 per cent of all municipal companies (type 3), compared with 66 per cent in 2003. Further, public law company forms are the inter-municipal company (IKS), based on the Inter-Municipal Company Act of 1999 (type 2) and the municipal firm (KF), regulated according to an amendment of 1999 in the Local Government Act (type 1). The IKS is, like the AS, a separate legal entity with its own board of directors. However, it is not a limited liability company like the AS; the participating municipalities are responsible for the IKS's total economic obligations on a pro-rata basis. The KF, however, does not hold a separate legal status.

Given our focus on waste management, the IKS and the AS are the most relevant and interesting forms of municipal companies. After a period of considerable reorganisation, from in-house and private sector provision to provision through inter-municipal companies, the inter-municipal companies represent the most prevalent form in terms of the total number of municipalities that they serve; now 334 municipalities out of a total of 428 municipalities (78 per cent) cooperate in almost 60 IKS-form companies; 63 organise their waste services through 17 inter-municipal AS-companies, whereas 28 municipalities run this service in-house (see Table 2). In addition, some municipalities have exposed their waste service to competitive tendering, resulting in (often partially) out-of-municipality provision, either by public companies from other municipalities or private companies. All in all, waste management appears to be one of the municipal services in Norway with the highest degree of variation in organisational forms (The competition authorities of the Nordic countries, 1998). 


\section{The Netherlands (1980s onwards)}

In comparison with Norway, in the Netherlands at the end of the seventies the interest in contracting out and inter-municipal cooperation with regard to waste collection had already increased. One of the most important arguments for contracting out or cooperating with other municipalities was to improve the efficiency of policy implementation and to reduce costs as an answer to the need to achieve cutbacks and enhance the quality of public services (Van Thiel, 2004). The expectation was that the market could perform some of the tasks more efficiently and effectively (Ter Bogt, 1998). Furthermore, smaller municipalities in particular expected to gain economies of scale by contracting out or cooperating with other municipalities. Another argument for these reforms was to separate policy and administration so that politicians, policy makers and policy implementers could concentrate on their core business (Van Thiel, 2004). The total number of tasks was growing rapidly, and, to prevent overload, it was held that tasks that were not genuinely public in character should not be provided by local governments.

Against this background, local governments rapidly changed the institutional form of waste collection. Consequently, a variety of institutional modes came into being. The two alternative modes that were chosen the most were contracting out to a private firm (type 4) and inter-municipal cooperation (type 2). In 1984, 249 municipalities out of a total of 750 municipalities (33 per cent) contracted out waste collection to a private firm (Bokkes, 1989). In the case of contracting out, activities are conducted by private organisations, but local governments are still engaged as commissioner (Ter Bogt, 2003). In this mode of production, local governments put the production of a service out to tender. Usually, the lowest bidder gets the award. Contracts differ in duration but are generally short-term for a fixed number of years (three to five) (Van Genugten, 2008).

The number of inter-municipal cooperations also increased in the period from 1978 to 
1982 by 112 municipalities (Bokkes, 1989). In the inter-municipal cooperations municipalities establish a separate legal entity, with transfer of authority, in which they have both governance (that is voting rights or a representative on the board) and financial interests (De Kruijf, 2011). These inter-municipal companies are mostly single purpose organisations and are established on the basis of public law (more specifically, the Joint Provisions Act). They take the form of a public body or joint organ. The participating municipalities - burgomaster, aldermen or members of the local councils are members of the supervisory board and the board of directors and in that role have final responsibility. Furthermore, local governments enter into service level agreements in which the requirements of the tasks are stipulated. Governments can only withdraw from the inter-municipal company by paying a fine (Van Genugten, 2008).

At the end of the 1990s a new institutional mode became popular in the Netherlands: the private law based limited company (type 3). After 2000, Dutch local governments increasingly chose this institutional form because they were experiencing high decisionmaking costs because of the multiple board levels in the public law based intermunicipal cooperations. They were hesitant to contract out to private firms because they did not think that the continuity and quality of service delivery could be guaranteed. With a limited company, they expected to stay in control of the company, while at the same time benefiting from the scale effects - most limited companies are owned by more than one municipality - and therefore a reduction of costs.

Like inter-municipal cooperations, limited companies are separate legal entities at arm's length from the local administration. Local governments are shareholders of the company and at the same time, as commissioners, they have a long-term contractual relationship with the limited company as their agent (Van Genugten, 2008). Local governments have crucial powers by virtue of their shareholding. For example, they have powers to appoint and discharge the executive board and the supervisory board of the limited company and to influence the main lines of its strategic policy (Van Genugten, 
2008). Furthermore, local governments enter into service level agreements in which the requirements of the tasks are stipulated. Aspects of the production of the public service, for example quantity, quality and price, are specified in the contract. Governments can only withdraw from the limited company by paying a fine (Van Genugten, 2008). The rise in limited companies in this period is primarily at the expense of in-house municipal services, although there is a small decline in contracting out to a private firm and intermunicipal cooperation too.

In 2014, one in six municipalities collected waste themselves, while in one third of the municipalities waste collection was organised by a limited company, and in another third it was contracted out to a private firm (see Table 2). Contracting out to private companies is still mainly chosen by small municipalities, while municipal services can mainly be found in large municipalities (Rijkswaterstaat Leefomgeving, 2014).

\section{Effects of NPM reforms in both countries}

As to the effects of different forms of organising waste collection and treatment in Norway and the Netherlands, only a few studies are available. In a Norwegian study, Sørensen (2007) argues that in some cases dispersed and indirect ownership, as in intermunicipal companies, leads to efficiency losses that are greater than the gains of economies of scale. User fees and costs are about 10 per cent higher when waste services are provided by such companies compared with services provided by a single municipality. On the other hand, a couple of studies indicate that arm's length waste management stimulates entrepreneurship and innovation (Smith, 2014; Andersen \& Torsteinsen, 2015).

In the Netherlands, studies have mainly investigated the economic effects of the different institutional forms. Based on 1996-data Dijkgraaf and Gradus (2003) show that on average outside provision leads to 15 per cent lower total costs than in-house provision. In two later studies, they show that this result is not stable over time. The cost 
advantage of private provision in the period 1998-2010 is much larger at the beginning than at the end, when costs for municipalities with private provision rise significantly (Dijkgraaf \& Gradus, 2008). Furthermore, short-term contracts (up to 5 years) with private providers are nearly always the most cost-saving option. However, overall the cost advantage of inter-municipal cooperation turns out be larger than private provision (Dijkgraaf \& Gradus, 2013). In addition, a study of the transaction costs of the different institutional forms shows that municipalities with a limited company have a higher level of transaction costs than in-house provision and municipalities that contract out to private firms (Van Genugten, 2008).

\section{Post-NPM - has it started?}

There are few if any signs of a post-NPM development in Norwegian municipalities. However, the share of municipalities practising the agency model has levelled off and lately decreased (Blåka et al., 2012). Also, most municipalities have started to merge some of their agencies into larger organisational entities (Olsen \& Torsteinsen, 2012). As for municipal companies, the growth in numbers also seems to have levelled off lately (Bjørnsen et al., 2015). At the same time, we find no convincing signs of municipalities dissolving municipal companies and moving tasks back in-house. Quite the opposite, there are increasing pressures from the EU to liberalise the waste market and open it up to private business, an idea that seems to be met with sympathy in the liberalconservative government now in power. This being said, many municipalities seem to have kept at least rudimentary administrative functions in-house to oversee the statutory obligations linked to waste management.

Nor do we find any signs of post-NPM development in local waste collection in the Netherlands. In 2015, after decades of institutional change, the waste market can be qualified as rather stable. In the future only incidental changes are to be expected or changes that will be the result of the reduction of the number of Dutch municipalities because of municipal amalgamations. 


\section{Comparison of reform trajectories}

Comparing the institutional developments in Norway and the Netherlands, we observe that local waste management has undergone many reforms in both countries. First, the Netherlands seems to enter the NPM-age a decade before Norway. In the Netherlands we observe the enactment of many reforms in the 1980s and the rise of a large diversity of types, namely type 1, 2 and 4 agencies, while reforms are still limited in Norway at that time, with type 0 agencies as the main form and some type 4 agencies. Second, from 1990 to the present, we observe the development of type 3 agencies in the Netherlands, although other types remain popular. In comparison, there are more reforms in Norway in this period with the rise of type 1, 2 and 3 agencies. In the postNPM stage, we observe a consolidation of a large variety of comparable institutional forms in both countries with an emphasis on inter-municipal cooperation. In Norway the inter-municipal company (type 2) is the dominating organisational form, while in the Netherlands the limited company (type 3) and contracting out (type 4) are the most prevalent forms.

Table 2. Institutional forms of waste management in Norway and the Netherlands 2013-2014

\begin{tabular}{llcccc}
\hline Type & $\begin{array}{l}\text { Institutional } \\
\text { form }\end{array}$ & \multicolumn{2}{c}{ Norway } & \multicolumn{2}{c}{ The Netherlands } \\
\hline & $\begin{array}{c}\text { No. of } \\
\text { munici- } \\
\text { palities } \\
\text { (M) }\end{array}$ & $\begin{array}{c}\text { Per cent } \\
\text { of M }\end{array}$ & $\begin{array}{c}\text { No. of } \\
\text { munici- } \\
\text { palities } \\
\text { (M) }\end{array}$ & $\begin{array}{c}\text { Per cent } \\
\text { of M }\end{array}$ \\
\hline $\mathbf{0 \& 1}$ & $\begin{array}{l}\text { In-house, } \\
\text { decentralised } \\
\text { \& agentified } \\
\text { units }\end{array}$ & 28 & 6.6 & 60 & 15 \\
\hline $\mathbf{2}$ & $\begin{array}{l}\text { Inter- } \\
\text { municipal } \\
\text { companies }\end{array}$ & 334 & 78.0 & 60 & 15 \\
\hline $\mathbf{3}$ & $\begin{array}{l}\text { Limited } \\
\text { companies }\end{array}$ & 63 & 14.7 & 121 & 30 \\
\hline $\mathbf{4}$ & \begin{tabular}{l} 
Contracting \\
\hline
\end{tabular} & 3 & 0.7 & 145 & 36 \\
\hline
\end{tabular}


out to

public* or

private

companies

Sum $\quad 428 \quad 100.0 \quad 386 \quad 96^{* *}$

Source: Norway, based on www.loop.no and own calculations; the Netherlands, based on Rijkswaterstaat Leefomgeving (2014). *municipal, inter-municipal, limited companies and so on

$* *$ only $96 \%$ of the Dutch municipalities are included here because $4 \%$ of the municipalities have an institutional form that does not fit into the typology.

In spite of the fact that the Netherlands was hit hard by the oil crisis in the 1970s and the financial crisis in 2008, while Norway was hardly hit at all, both countries have developed relatively similar organisational solutions for municipal waste, although they were introduced at different points in time. This could indicate similarities in institutional conditions (decentralised public service provision, strong local identities), isomorphic pressures (NPM-inspired agentification) and structural configurations (municipalities too small to harvest the economies of scale necessary for waste management).

\section{Conclusion}

The reform trajectory of waste management in Norway and the Netherlands does not match the three developmental stages discussed in the introduction. Moreover, there are significant differences in the reform trajectories of Norway and the Netherlands. In the Netherlands the most significant NPM-related changes (second stage) have taken place in the 1970s and 1980s, while in Norway these have taken place from the 1990s onwards. Nonetheless, increasing agentification seems to be a common feature. In relation to the last stage, we do not find any convincing signs of re-municipalisation in the field of waste management. The main explanation for this is that the influence of NPM in these countries never led to the massive de-municipalisation and privatisation of local services - and more specifically waste management - that seem to have affected the larger European societies, for example Germany (Dreyfus et al., 2010). Although agentification has left its mark on local government in Norway and the Netherlands, 
ownership has always been and still is mostly in the hands of local government. Instead of re-municipalisation we observe a strong focus on inter-municipalisation in a variety of forms.

\section{References}

Andersen, O. J. \& Torsteinsen, H. (2015). 'Selskapsreisen: En casestudie av fristilling som innovasjonskatalysator' in Andersen, O. J., Bondas, T. \& Gårseth-Nesbakk, L. (Eds) Innovasjon i offentlig tjenesteyting (Bergen: Fagbokforlaget), pp. 215-236.

Bjørnsen, H. M., Klausen, J. E. \& Winsvold, M. (2015). Kommunale selskap og folkevalgt styring gjennom kommunalt eierskap. Rapport 2015:1 (Oslo: Norsk institutt for by- og regionforskning (NIBR)).

Blåka, S., Tjerbo, T. \& Zeiner, H. (2012). Kommunal organisering 2012. Redegjørelse for Kommunal- og regionaldepartementets organisasjonsdatabase. Rapport 2012: 12 (Oslo: NIBR).

Bokkes, W. (1989). Privatisering Belicht vanuit de Transactiekostenbenadering. Ph.D. thesis (Enschede: Universiteit Twente).

De Jong, P., \& Wolsink, M. (1997). 'The Structure of the Dutch Waste Sector and Impediments for Waste Reduction', Waste Management \& Research, 15, 641-658. 
De Kruijf, J.A.M. (2011). 'Controlling Externally Autonomised Entities by Dutch Local Governments', International Journal of Productivity and Performance Measurement, $60(1), 41-58$.

Dijkgraaf, E. \& Gradus, R. (2003). 'Cost Savings of Contracting out Refuse Collection', Empirica, 30(2), 149-161.

Dijkgraaf, E. \& Gradus, R. (2008). 'Institutional Developments in the Dutch Waste Collection Market', Environment and Planning C: Government and Policy, 26(1), 110126.

Dijkgraaf, E. \& Gradus, R. (2013). 'Cost Advantage Cooperations Larger than Private Waste Collectors', Applied Economics Letters, 20, 702-705.

Dreyfus, M., Töller, A. E., Iannello, C. \& McEldowney, J. (2010). 'Comparative Study of a Local Service: Waste Management in France, Germany, Italy and the UK' in Wollmann, H. \& Marcou, G. (Eds) The Provision of Public Services in Europe. Between State, Local Government and Market (Cheltenham: Edward Elgar), pp. 146-167.

Hulst, R. (2005). 'Regional Governance in Unitary States: Lessons from the Netherlands in Comparative Perspective', Local Government Studies, 31(1), 99-120. 
John, P. (2001). Local Governance in Western Europe (London: Sage).

Klausen, K. K. \& Ståhlberg, K. (1998). 'New Public Management' in Klausen, K. K. \& Ståhlberg, K. (Eds) New Public Management i Norden (Odense: Odense Universitetsforlag), pp. 9-31.

Lidström, A. (1996). Kommunsystem i Europa (Stockholm: Publica).

Löffler, E. (2003). 'The Administrative State in Western Democracies' in Peters, B. G. \& Pierre, J. (Eds) Handbook of Public Administration (London: Sage), pp. 478-488).

Olsen, J. P. (1996). 'Norway: Slow Learner - or Another Triumph of the Tortoise?' in Olsen, J. P. \& Peters, B. G. (Eds) Lessons From Experience (Oslo: Scandinavian University Press).

Olsen, T. H. \& Torsteinsen, H. (2012). 'Enhetslederrollen' in Torsteinsen, H. (Ed.) Resultatkommunen. Reformer og resultater (Oslo: Universitetsforlaget ), pp. 125-142.

Pollitt, C., Talbot, C., Caulfield, J. \& Smullen, A. (2004). Agencies: How Governments Do Things through Semi-Autonomous Organizations (Houndmills: Palgrave Macmillan).

Rijkswaterstaat Leefomgeving. (2014). Afvalstoffenheffing 2014 (Utrecht: Rijkswaterstaat 
Leefomgeving).

Ringkjøb, H.-E., Aars, J. \& Vabo, S. I. (2008). Lokalt folkestyre AS. Eierskap og styringsroller i kommunale selskap. Rapport 1/2008 (Bergen: Rokkansenteret).

Smith, E. (2014). 'Entrepreneurship at the Local Government Level', Public Management Review, 16(5), 708-732.

Sørensen, R. (2007). 'Does Dispersed Public Ownership Impair Efficiency? The Case of Refuse Collection in Norway', Public Administration, 85(4), 1045-1058.

Statistics

Norway

(2008).

Samfunnsspeilet

2008/5-6,

http://www.ssb.no/nasjonalregnskap-og-konjunkturer/artikler-og-publikasjoner/det-

svinger-i-norsk-okonomi, date accessed 19 March 2015.

Ter Bogt, H. (1998). Neo-Institutionele Economie, Management Control en Verzelfstandiging van Overheidsorganisaties. Ph.D. thesis (Groningen: Rijksuniversiteit Groningen).

Ter Bogt, H. (2003). 'A Transaction Cost Approach to the Autonomization of Government Organizations: A Political Transaction Cost Framework Confronted with Six Cases of Autonomization in the Netherlands', European Journal of Law and Economics, 16(2), 
149-186.

The competition authorities of the Nordic countries (De nordiske konkurransemyndigheter) (1998). Konkurranseutsetting av kommunal virksomhet.

$\begin{array}{lll}\text { Rapport nr. 1/1998, } & \text { ne }\end{array}$ http://www.konkurransetilsynet.no/iKnowBase/Content/395675/98 1 KONKURRANSEU TSETTING KOMMUNAL VIRKSOMHET.PDF, date accessed 25 June 2015.

Torsteinsen, H. (2012). 'Bakgrunn, diagnose og inspirasjon' in Torsteinsen, H. (Ed.) Resultatkommunen. Reformer og resultater (Oslo: Universitetsforlaget ), pp. 23-36.

Van Genugten, M. L. (2008). The Art of Alignment. Transaction Cost Economics and Public Service Delivery at the Local Level (Enschede: University of Twente).

Van Thiel, S. (2004). 'Quangos in Dutch Government' in Pollitt, C. \& Talbot, C. (Eds) Unbundled Government: A Critical Analysis of the Global Trend to Agencies, QuasiAutonomous Bodies and Contractualization (London: Routledge), pp. 167-183.

Van Thiel, S. (2012). 'Comparing agencies across countries' in Verhoest, K., Van Thiel, S., Bouckaert, G. \& Lægreid, P. (Eds) Government Agencies: Practices and Lessons from 30 Countries (Houndmills: Palgrave Macmillan), pp. 18-26. 
Vereniging van Nederlandse Gemeenten (1979). Gemeente en Afvalstoffenwet. Het zich Ontdoen en het Inzamelen van Huishoudelijke en Andere Afvalstoffen (Den Haag: Uitgeverij van de Vereniging van Nederlandse Gemeenten).

Wollmann, H. \& Marcou, G. (Eds) (2010). The Provision of Public Services in Europe. Between State, Local Government and Market (Cheltenham: Edward Elgar). 